\title{
Design of seismic-resistant linings for rock burst conditions
}

\author{
Vitalii V. Glinskii \\ Postgraduate student, Saint-Petersburg Mining University, Saint-Petersburg, Russian Federation \\ V.L. Trushko \\ D.E.Sc., full professor, Saint-Petersburg Mining University, Saint-Petersburg, Russian Federation
}

\begin{abstract}
In the deep horizons development of deposits, mining and geological and technical conditions are significantly complicated. In mine workings dynamic phenomena are appeared, therefore they lead to performance decline of mining enterprises and injuries of miners. Actual task is the development of designs and justification of the rational parameters of seismic-resistant reinforcing linings, ensuring the stability of the mine workings throughout the entire period of their exploitation and the safety of mining. An analysis of the experience of using reinforcing rockbolt linings in Russian and foreign mining enterprises and a comparative assessment of seismic resistance and the effectiveness of using various types of rockbolts. The basic requirements for reinforcing rockbolt linings are formulated to ensure the stability of mine workings in the conditions with dynamic phenomena. As a result of research, it was found that the most effective application of frictional rockbolts, since they come into operation immediately after installation, retain high bearing capacity under dynamic stresses $(75-110 \mathrm{kN})$.
\end{abstract}

\section{INTRODUCTION}

In the development of deep horizons of deposits, geological and mining and technical conditions are greatly complicated. Dynamic phenomena such as rock bump reduce the efficiency and productivity of the mining enterprise and lead to injuries to miners. Proceeding from this, the development of rational parameters of seismic-resistant reinforcing linings, which ensure the stability of the mine workings, the reliable maintenance throughout the entire period of their exploitation, the safety of mining operations and the constancy of the mining enterprise's work, becomes an actual task in the development of deep deposits.

Mainly combined seismic-resistant rockbolt linings in mine workings with the manifestation of dynamic phenomena from rock bump and mass explosions in preparatory mine workings and used coupling (Chunlin $\mathrm{Li}, \mathrm{C}$. 2010). The relatively recent studies have shown that friction-type rockbolt linings have the highest strength and deformation indicators.

Exploitation reliability in mine workings, which liable to dynamic loads and in areas, which affected by mass explosions is low. The wooden lining in this case has low efficiency, because the beams are destroyed, the legs are pressed inside the output contour. Dumps and the zone of destroyed rocks in the roof, depending on the type of rock, reach 2-3 $\mathrm{m}$. The arch malleable lining doesn't provide the necessary stability of mine workings, because such phenomena as deflection of the upper part of the lining, breaks of clamps, and destruction of the tie lead to a loss of stability of the lining structure with increasing deformations.

The main reason for the low efficiency of the considered lining constructions under dynamic phenomena is the discrepancy between the work mechanism of the deformation processes arising in rocks under the action of seismic waves. 


\section{REQUIREMENTS FOR ROCKBOLT LININGS}

The designed rockbolt lining must satisfy the following requirements (Trushko V.L., Protosenya A.G., Matveev P.F., Sovmen H.M. 2000) to ensure the stability of mine workings in the conditions of dynamic forms of rock pressure manifestations:

- providing functional purpose in economic and technological ways;

- starting working in a short time after installation (up to 3-6 hours);

- assumption of a change in the shape and size of the cross section of the mine when it's position in space deviates from the initial one,

- assumption of a change in the direction and magnitude of the maximum static and dynamic stresses in the rock mass, without a significant change in the construction of the elements and the technology of erection lining;

- maximum use of the own load-bearing capacity of the rock mass, including due to it's hardening to the level necessary to perceive the total influence of static and dynamic loads for the required period;

- providing the possibility of reinforcing the originally selected lining in zones of influence of increased seismic effects, tectonic disturbances, couplings of mine workings stoping without significantly changing the constructional elements of the lining;

- ensuring the stability of the mine workings in conditions with genesis of oscillatory processes in the border zone of rock mass;

- preservation of the load-bearing capacity and stability of the lining interaction with the rock mass under periodic exposure to dynamic phenomena.

The peculiarities of the work of rockbolt linings are determined by the variability of the distribution of stress fields in the tectonically active rock mass, the random character of the dynamic influences on the lining, and the frequent change of geological conditions during mining works.

Based on this, the type and parameters of lining are chosen for typical mining, geological and technological conditions of the designed mine working, providing for the possibility of changing both the shape of its cross section and the parameters of the lining during the period of mining works.

Rockbolt linings must satisfy the following technological and design requirements for implementation these conditions:

- ensuring the stability of production and the safety of work in it throughout the entire service life;

- quick entry into work, preservation of the calculated load-bearing capacity and resistance to dynamic influences throughout the entire service life of the lining;

- assumption of changing the shape of the cross section of the mine working without changing the construction of the lining;

- possession of an effective reinforcing effect on the rock mass;

- increasing the load-bearing capacity of the border zone of the rock mass in order to prevent loss of stability of the mine working in areas of possible dynamic manifestations of rock pressure;

- possession of the necessary amortizing properties (compliance) during the development of oscillatory processes in the rock mass under the influence of dynamic phenomena;

- the possession of increased load-bearing capacity, necessary in conditions of highly weakened rocks around the output contour of mine working;

- the lining construction must be technologically advanced in the manufacture and construction, transportable, accessible for monitoring the load-bearing capacity and maintenance during exploitation.

\section{ROCKBOLT LINING GROUPS}

In the mining industry of the Russian Federation are mainly classical types of linings such as shotcrete and rockbolt lining from supporting structures - compliant metal lining and monolithic concrete lining are used. 
As seismic-resistant linings it's recommended to use reinforcing constructions of rockbolt linings and combined linings, which preserve the calculated load-bearing capacity and stability under the influence of seismic effects and throughout the entire period of exploitation (Wen, J., Yang, C., Su, H., \& Ning, D. 2015). The rockbolts should come into work quickly after installation and have contact with the rock mass along the entire length of the rockbolt (Gospodarikov, A. P., \& Zatsepin, M. A. 2019).

Consider the traditional types of rockbolt constructions used in the mining industry of the Russian Federation which have been successfully tested in domestic mines.

As a seismic-resistant rockbolt constructions were fastened, which are retaining the loadbearing capacity under the influence of seismic effects (Li, C. C., Stjern, G., \& Myrvang, A. 2014). This condition is most satisfied with the rockbolt, which had the presence of continuous contact with a massive. Based on this in this work two groups are considered: first group is rockbolts which are entering into work immediately or shortly after installation; second group is rockbolts which are entering into work after several hours of installation (Li, C. C. 2017).

The first group includes following rockbolts:

(1) Combined cemented roof rockbolt (CCRR). This slot-and-wedge rockbolt (Figure 1) is a structure that has a wedge-slot metal rockbolt with a modified wedge as reinforcement, which is fixed in the array by both the wedge itself and the cement-sand mortar that fills the well along the entire length before the rockbolt is inserted into it. Designs of this rockbolt are selected to specific conditions, changing the length of the rockbolts, the diameter of the rockbolts, the density of their placement, the diameter of the wire mesh, the thickness of the shotcrete and the backlog of the lining from the face of mine working (Small, J. C. 2016).

(2) Frictional rockbolt type Swellex (FR). This frictional rockbolt (Figure 2) consists of a special hollow pipe with a C-shaped cross section with plugs at the ends, which is fixed in the well by the pressure of a special fluid pumped into the pipe (Li, D., Masoumi, H., Saydam, S., \& Hagan, P. C. 2018).

(3) Resin-grouted roof rockbolt (RGRR). Steel and polymer rockbolt (Figure 3) are lock and solid, consisting of a reinforcing bar, ampoules with polymer concrete components, a nut and a base plate (Protosenya A.G., Kolosova O.V., Ogorodnikov Y.N. 2003).

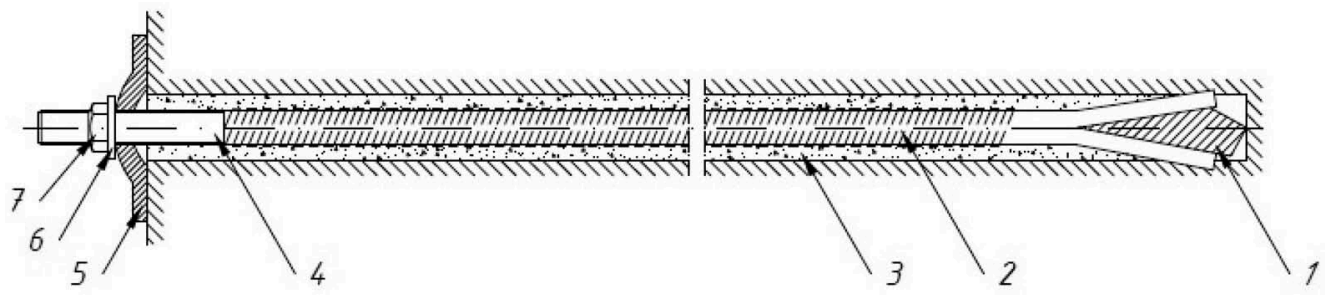

Figure 1. Combined cemented roof rockbolt (1 - metal wedge, 2 - rod of circular or periodic profile, 3 cement-sand mortar, 4 - section of the rod with thread, 5 - base plate, 6 - spacing washer, 7 - tension nut).

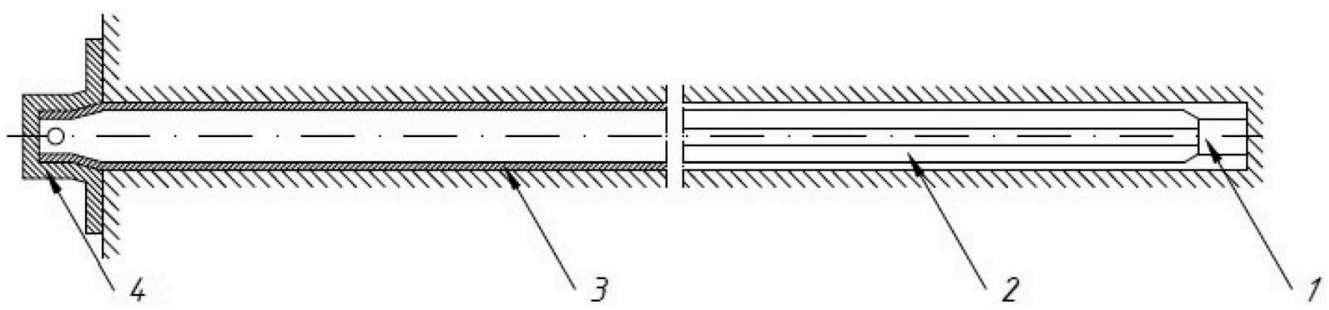

Figure 2. Frictional rockbolt type Swellex (1 - a sealed rockbolt shank, 2 - a special section hollow pipe before liquid injection, 3 - a special section hollow pipe after liquid injection, 4 - a special type base plate). 

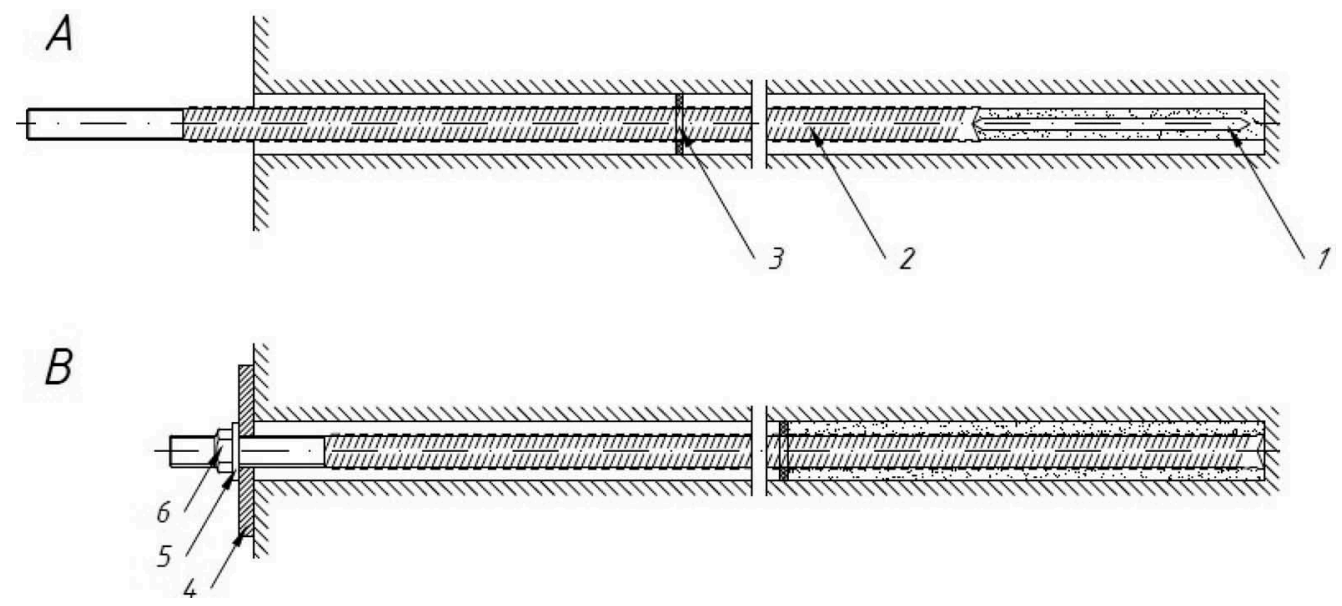

Figure 3. Resin-grouted roof rockbolt during installation (a) and after it (b) (1 - a steel rod of a periodic profile, 2 - quick-hardening composition based on synthetic resins, 3 - a rubber ring, 4 - a base plate, 5 spacing washer, 6 - a tension nut).
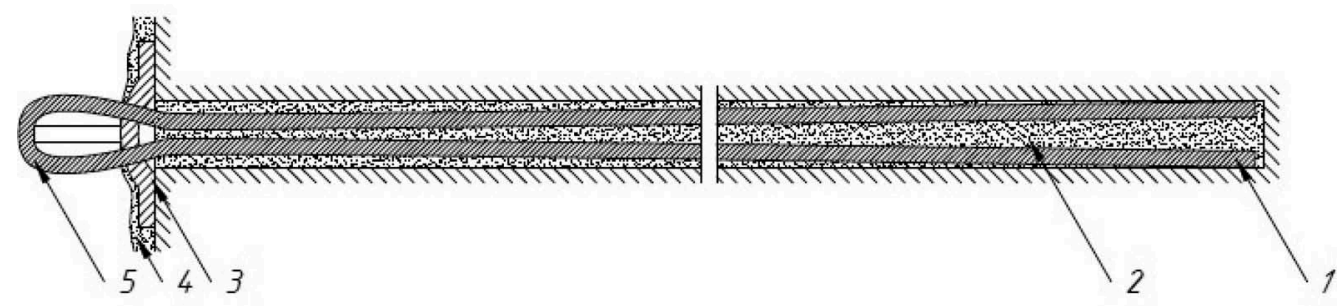

Figure 4. Cable rockbolt (1 - wire rod, 2 - cement-sand mortar, 3 - special wedge-shaped supporting element, 4 - shotcrete, 5 - hinge of wire rod).

The second group includes following rockbolt:

(1) Cable rockbolt (CR). This rockbolt (Figure 4) consists a loop end, an oval-type base plate with a notch and a special locking wedge (Trushko O.V. 2016).

\section{TASKS OF WORK}

The first task is determination of the load-bearing capacity of seismic resistant rockbolts in rock mass, exposed to dynamic effects.

The second task is testing construction technologies of seismic resistant rockbolts and the estimation of their labor intensity.

\section{METHODOLOGY}

The tests were carried out in the conditions of the Severouralsk bauxite mines in the limestone rocks with a compressive strength of 62-75 MPa at a depth of 200-400 m. Each type of rockbolt had a length of $2.5 \mathrm{~m}$. and a diameter of $36 \mathrm{~mm}$.

The tests were as follows:

(1) One rockbolt of each type was installed in a specific mining area; 
(2) Measurements were made of the installation time of each of the rockbolts to determine the complexity of the work and the average time for each type of rockbolt was displayed;

(3) Throughout the day, data on the bearing capacity of each of the rockbolts were recorded. The first measurements were made at the installation stage if it was possible to make the installation technology of the rockbolt. Then the measurements were made after 1 hour, 2 hours and 24 hours.

\section{ANALYSIS OF RESULTS}

Average results of mining tests in Table 1 are presented.

Table 1. Average results of mining tests.

\begin{tabular}{|c|c|c|c|c|c|c|}
\hline \multirow[b]{2}{*}{ Rockbolt type } & \multirow{2}{*}{$\begin{array}{l}\text { Number of } \\
\text { tested } \\
\text { structures }\end{array}$} & \multicolumn{4}{|c|}{$\begin{array}{l}\text { Average load-bearing capacity of the rockbolt } \\
(\mathrm{kN}) \text { from the moment of installation (hour) }\end{array}$} & \multirow{2}{*}{$\begin{array}{l}\text { Unit labor for installa- } \\
\text { tion of one rockbolt } \\
\text { (person per hour) }\end{array}$} \\
\hline & & 0 & 1 & 2 & 24 & \\
\hline $\begin{array}{l}\text { Combined } \\
\text { cemented roof } \\
\text { rockbolt (CCRR) }\end{array}$ & 3 & 69 & - & - & 110 & 0,16 \\
\hline $\begin{array}{l}\text { Cable rockbolt } \\
\text { (CR) }\end{array}$ & 4 & 0 & - & - & $60-85$ & 0,18 \\
\hline $\begin{array}{l}\text { Resin-grouted } \\
\text { roof rockbolt } \\
\text { (RGRR) }\end{array}$ & 3 & $0-60$ & 80 & 140 & 180 & 0,18 \\
\hline $\begin{array}{l}\text { Frictional rock- } \\
\text { bolt (FR) }\end{array}$ & 2 & $100-110$ & $100-110$ & $100-110$ & $100-110$ & 0,10 \\
\hline
\end{tabular}

When analyzing the results, the following conclusions were generated:

(1) The load-bearing capacity of the CCRR ensures normal exploitation and it may apply as a permanent lining;

(2) RGRR tests have shown high performance. Due to the application of polymer concrete with high-strength fast-acting composition, it was possible to achieve rapid entry into work. RGRR has a high resistance to seismic effects and can be used such as temporary and permanent linings;

(3) Experimental data showed that FR is the most effective of the common constructions. FR come into exploitation immediately after installation and have high load-bearing capacity $(100-110 \mathrm{kN})$. FR has contact with the rock along the entire length and it is technological in installation (the average installation time of the rockbolt was not more than $1 \mathrm{~min}$, excluding drilling of the hole);

(4) The technology of CR construction and their load-bearing capacity are less than CCRR, which ensures their normal exploitation and it may apply as a permanent support. However, the slow curing of concrete strength does not allow the use of CR such as a temporary lining.

\section{CONCLUSION}

Due to the high seismic resistance of FR, high and constant load-bearing capacity, workability, this rockbolt construction can be recommended as rockbolt in difficult mining and geological conditions with exposed to dynamic forms of rock pressure.

It can be used both as temporary and as permanent lining. 


\section{REFERENCES}

Chunlin Li, C. 2010. A new energy-absorbing bolt for rock support in high stress rock masses. International Journal of Rock Mechanics and Mining Sciences, 47(3), pp.396-404. https://doi.org/10.1016/ j.ijrmms.2010.01.005

Gospodarikov, A. P., \& Zatsepin, M. A. 2019. Mathematical modeling of boundary problems in geomechanics. Gornyi Zhurnal, 2019(12), 16-20. doi:10.17580/gzh.2019.12.03

Li, C. C., Stjern, G., \& Myrvang, A. 2014. A review on the performance of conventional and energy-absorbing rockbolts. Journal of Rock Mechanics and Geotechnical Engineering. Chinese Academy of Sciences. https://doi.org/10.1016/j.jrmge.2013.12.008

Li, C. C. 2017. Principles of rockbolting design. Journal of Rock Mechanics and Geotechnical Engineering, 9(3), 396-414. doi:10.1016/j.jrmge.2017.04.002

Li, D., Masoumi, H., Saydam, S., \& Hagan, P. C. 2018. Mechanical Characterisation of Modified Cable Bolts Under Axial Loading: An Extensive Parametric Study. Rock Mechanics and Rock Engineering, 51 (9), pp. 2895-2910. https://doi.org/10.1007/s00603-018-1475-4

Protosenya A.G., Kolosova O.V., Ogorodnikov Y.N. 2003. Seismic-resistant designs of lining of mine workings in the development of shock-hazardous deposits. Journal of Mining Institute, 154, pp. 153-156.

Small, J. C. 2016. Geomechanics in soil, rock, and environmental engineering. Geomechanics in soil, rock, and environmental engineering, pp. 1-535

Trushko V.L., Protosenya A.G., Matveev P.F., Sovmen H.M. 2000. Geomechanics of massifs and dynamics of deep mine workings. Saint-Petersburg Mining Institute, p. 396.

Trushko O.V. 2016. Types and designs of antiseismic lining a used in the development of ore deposits. "Izvestiya Tula State University" (Izvestiya TulGU), pp. 120-130.

Wen, J., Yang, C., Su, H., \& Ning, D. 2015. Theoretical analysis and application of composite arch for bolt-shotcrete steel frame supported tunnel in weak and fractured rock mass. Tumu Gongcheng Xuebao/China Civil Engineering Journal, 48(5), 115-122. 